\title{
PRODUCTION BASED LEARNING: AS A TOOL TO INCREASE ENTREPRENEURIAL SKILLS OF STUDENTS
}

\author{
Ganefri, Aznil Mardin, Ulfia Rahmi, Asmar Yulastri \\ Faculty of Engineering, Padang State University, Indonesia \\ Faculty of Tourism and Hospitality, Padang State University, Indonesia
}

\begin{abstract}
The aim of this paper is to examine the issue of the development of entrepreneurial skills of students in vocational education. Entrepreneurship education is a subject that is included in the curriculum of vocational education which aims to broaden the knowledge of the students to the world of entrepreneurship and to motivate them to become directly involved in the entrepreneurial world. However, the achievement of the objectives of the course is still far from what is expected, it is caused by the lack of experience gained by the students in the entrepreneurial course and by the lack of student ability to generalize from one course to the other courses. The recent learning process oriented on the theory that was less supported by the practice, so that the experiences gained were still abstract. The teaching model of production based learning is the main step in improving the entrepreneurial skills of the learners, it is caused by this model will synergize the knowledge (cognitive) and psychomotor abilities of students that have not been achieved well. The implication is that faculty and instructional designers need to design the learning that facilitates the students in order to have direct experiences especially in entrepreneurial courses (entrepreneurship).
\end{abstract}

Keyword: Models of Teaching, Product Based Learning, Entrepreneurship,

\section{INTRODUCTION}

Asean Economic Community (AEC) is a free trade system agreed upon by the ASEAN countries, this era makes the competition of workforce becomes more competitive and it will require the citizens of the country to improve their ability to create their own jobs. Therefore, the community and higher education graduates have to change the paradigm of being a job seeker to be a job creator.

Associated with it, before the advent of MEA, Indonesia has already been faced with the challenges of the economy. Among them, the high number of unemployment with higher education is the sample, then the lack of due skill of a particular educational unit with the needs of the market (industry), so that the ability of graduates of higher education are less competitive in the national and international levels. [10] found that the promotion of entrepreneurship is dedicated to prevent of violence in Rio deJaneiro. Yet our own country still faces many problems both of the curriculum (goal object) and the lack of teachers' experiences in the field of business and entrepreneurship. A number of empirical research shows that formal education fails to achieve the target of entrepreneurship education. The contribution of vocational high school in this case is questioned by many sides, because many graduates who do not meet the required qualifications by this sector at the same time are not ready to become an entrepreneur [1].

Various efforts have been made to resolve the problem. One of them is by an entrepreneurship idea among the people. However, the idea of entrepreneurship is difficult to be applied because of the public mindset. In addition, entrepreneurial success depends on individual traits such as motivation, need for an achievement, perceptions of exogenous business factors, and the network of relationships [12].

The importance of the entrepreneurship implementation in Indonesia makes the issue of entrepreneurship is also drawn to the educational unit to tackle social and economic problems, started from primary, 
secondary and tertiary education. Including at the State University of Padang. Its implementation is supported by KKNI for each level of education units. In vocational education, entrepreneurship is one of the compulsory subjects. The problem is that the learning outcomes of the entrepreneurial course are not in line with expectations. The cause is that the lectures were still dominated by conceptual discussion which were minimal in practice to gain direct experience for the students. As studies [15] which addressed issues around learning, development of entrepreneurship, mentoring and matching mentors for entrepreneurs clients. In order to provide skills for students, the development of entrepreneurial learning has very important role as students learn from the experience or a critical incident that they did. This means that the learning to equip entrepreneurial skills will mean nothing when the students do not get a direct experience of the issues of what they are studying.

Furthermore, another study evaluates the educational company. The evaluation includes the purposes of the main pedagogical educational company, allowing students to grow and develop and establish their own identity in getting the learning experience. A case study of 18 cases / life stories of undergraduate entrepreneurs and their experiences of enterprise education from a university. [5] found that graduates who started their own businesses were reluctant to call themselves as "entrepreneurs", because the label given to them by the teachers and peers. It is associated with the paradigm which previously discussed that actually they did not realize that the competencies acquired were not built on entrepreneurship courses which were purely theoretical.

\section{DISCUSSION}

Entrepreneurship

Entrepreneurship education began to develop in 60s in the United States, in 1975 there had been more than one hundred universities in the United States that offered entrepreneurial courses. As the time went by the entrepreneurship education in the United States was encouraged by many business schools and universities that provided the concentration or specialization in entrepreneurship. Therefore, America became one of the advanced countries in almost all sectors, especially in the sectors of economies (figures of entrepreneurs which were pretty high).

Entrepreneurship process begins with an axiom, that is a challenge. The challenge arises from the idea, willingness and encouragement for the initiative, which is a creative thinking and innovative action, so that the challenge can be resolved. All challenges must have a risk; it is the probability of successful or unsuccessful. Therefore, an entrepreneur is a person who dared to risk and like the challenge [16]. In Indonesia, entrepreneurship education is not a new thing, because it began popping up in Indonesia in the 1980s, and in 2000s entrepreneurship education was encouraged to support the economy with the number of young entrepreneurs born in Indonesia. Then, Indonesian government began to encourage the development of entrepreneurship education through student activities, as well as by improving the quality of entrepreneurship education. However, entrepreneurship education in Indonesia was learned limited in some schools or colleges where the learning was just theoretical, so that the achievements of the expected on the entrepreneurship learning was not yet optimal, and as the result, the students were lack of understanding and experience about entrepreneurship.

Unlike Indonesia, European countries make entrepreneurship as the spearhead of education. They already apply and teach at all levels of education that exist in European countries. In the following table are the goals and objectives of entrepreneurship education in European countries [10]. 
Table 1. Entrepreneurship as aneducational responsibility for Europe.

\begin{tabular}{|c|c|c|c|}
\hline Target group & Objective & Entrepreneurship as & $\begin{array}{l}\text { Suggestions for } \\
\text { implementation }\end{array}$ \\
\hline $\begin{array}{l}\text { Children } \\
\text { (primary/ } \\
\text { secondary level }\end{array}$ & Familiarisation & Positive basic attitude & $\begin{array}{l}\text { Integration of economy } \\
\text { into } \\
\text { Syllabuses. }\end{array}$ \\
\hline \multirow[t]{2}{*}{$\begin{array}{l}\text { Young people } \\
\text { (vocationa ltraining) }\end{array}$} & Sensitisation & $\begin{array}{l}\text { Entrepreneurial attitude to } \\
\text { work }\end{array}$ & $\begin{array}{l}\text { Advanced teacher training } \\
\text { Promotion of key } \\
\text { competences } \\
\text { Integrated with subject } \\
\text { content }\end{array}$ \\
\hline & Maturity & $\begin{array}{l}\text { Occupation-based } \\
\text { introduction } \\
\text { To self-employment }\end{array}$ & $\begin{array}{l}\text { Method-based promotion } \\
\text { Subject-specific } \\
\text { supplementation } \\
\text { For particular occupations } \\
\text { (additional skills training/ } \\
\text { Optional components }\end{array}$ \\
\hline \multirow{4}{*}{$\begin{array}{l}\text { Adults } \\
\text { (continuing } \\
\text { education/training and } \\
\text { higher } \\
\text { educatio) }\end{array}$} & Competence & $\begin{array}{l}\text { Entrepreneurial working } \\
\text { behaviour }\end{array}$ & $\begin{array}{l}\text { Continuing training } \\
\text { For skilled workers }\end{array}$ \\
\hline & Optimisation & $\begin{array}{l}\text { (Enterprise) management } \\
\text { Competence and } \\
\text { competence } \\
\text { to set up in business }\end{array}$ & \multirow[b]{2}{*}{$\begin{array}{l}\text { Seminars on setting up in } \\
\text { business }\end{array}$} \\
\hline & & & \\
\hline & & & $\begin{array}{l}\text { Coaching, guidance, } \\
\text { workshops, seminars }\end{array}$ \\
\hline
\end{tabular}

\section{Curriculum}

The curriculum can be defined as the documents, plans, study programs, subjects and learning experiences $[4,12,17]$. The curriculum as a document means nothing when it is not supported by the quality of learning and improving the competence of lecturers (pedagogy). In order to implement the curriculum, it is needed to design the courses which are contained in the curriculum documents. The curriculum document is composed of the objectives of the study program, and subjects that are relevant to achieve the goals. Then, the courses will be the guidance to provide a learning experience to the students through the learning process.

Related to debriefing of the direct learning experience to the students, in Indonesia there is a framework for regulating the level of skill qualification according to the educational level. The framework is known as KKNI.

\subsubsection{Indonesia National Qualifications Framework (KKNI)}

Indonesian National Qualifications Framework (KKNI) in the field of higher education is a framework of qualifications level that can pair, equalize, and integrate the learning outcomes of the path of non formal education, informal education, and / or work experience in the types and levels of higher education [13].

The basic principle in the development of KKNI is to assess the competence and expertise of a person in accordance with the achievements of the scientific aspects of learning (Learning Outcome) acquired through education, training or experience gained through the process of education that is equivalent to the qualification descriptors at certain levels. The achievement of learning (learning outcomes) is the internalization and accumulation of knowledge, knowledge, skills, affection, and competencies achieved 
through a structured educational process and includes a field of science / specific expertise or through working experience [7] The term of learning outcome becomes popular in Indonesia at the time KKNI began in earnest as a reference for achievement equalizing between the producers (supply push) and the employment users (demand full). Thus, between formal education, professional development, community, and industry or the world of work can be integrated to meet the needs of all stakeholders as the user of graduates of formal education. For example, formal or informal education sector use KKNI as a reference to arrange the learning plan, so that the graduates who are equivalent to the needs of industry can be produced. Likewise industrial, the developer professionalism can refer to KKNI as consideration the qualifications of job seekers and positioning it as an appropriate career path, so that thegraduates of higher education can have a positive impact in the community with the increase of competitive human resources.

Conceptually, each qualification level in KKNI is composed by six main parameters, namely;

a. Science (science)

b. Knowledge (knowledge)

c. Practical knowledge (know-how)

d. Skills (skill)

e. Affection (affection)

f. Competence (competency)

All six parameters in each level are arranged in the form of a description which is called Qualification Descriptors. Thus, all nine levels of qualifications in KKNI contain descriptors that describe the capabilities in the areas of work, scope of work based on the essential knowledge and ability which is mastered [7].

KKNI consists of 9 level qualification frameworks starting from the lowest level of qualification which is qualification 1 to the highest qualification which is qualification 9. Figure 1 is a ladder of KKNI that becomes learning outcomes which is agreed nationally;

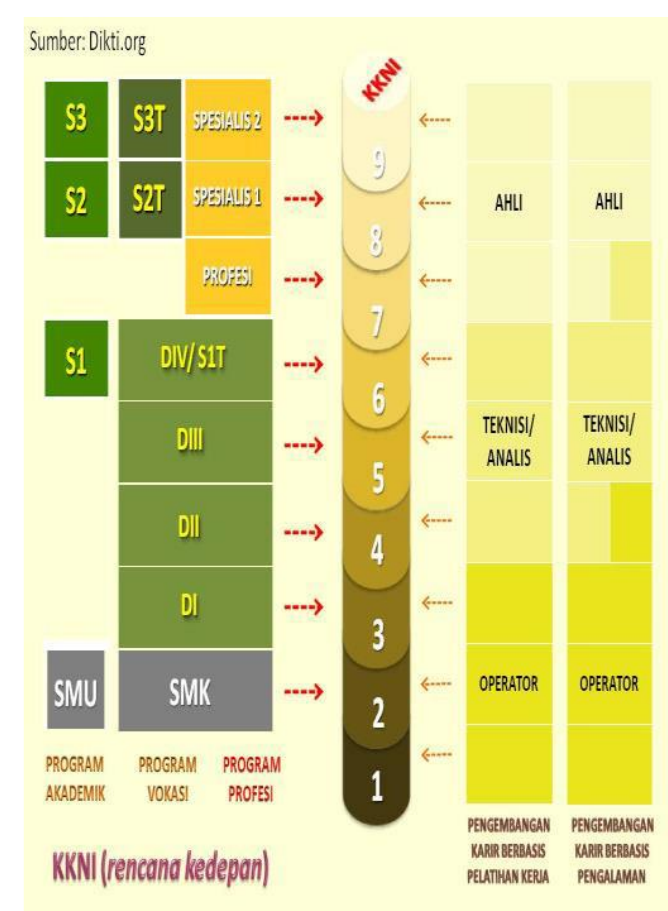

Fig.1 Indonesian National Qualifications Framework (KKNI) 


\section{Curriculum Content}

Curriculum content is arranged based on community needs by involving all stakeholders in the curriculum [4]. In presenting, it is by considering the organization of learning materials, which consider the scope, sequence, integration, balance articulation and continuity of the material [12]. When the material presented in the class, it should involve the students directly so that they can reconstruct the knowledge and experience they have. With these efforts, it is expected that the curriculum content is appropriate or relevant with the needs of students.

\section{PRODUCT BASED LEARNING}

The design of product based learning model is to understand the concepts being taught through the experience of working on objects directly in the workshop or in the field (practical experience), so that it can produce a product that meets industry standards ". In line with this matter, [6] also stated that: "the production-based learning models is defined as the procedures or steps that need to be performed by the educator to Facilitate learners to actively learn, participate and interact, with a competency-orientation to produce a product either goods or services required ".

Therefore, in the product based learning, it is designed to organize a structured learning environment and requires the students to be active during the implementation of learning. The product based learning can test students understanding by conducting guided practice and continue to encourage students to build their capacity to practice under the guidance of a teacher or professor.

This model should be preceded by an effective diagnosis of the initial knowledge and ability of the students to ensure them having capability to perform tasks in the product based learning practices. As well as with the application of entrepreneurial courses, if the students are often directly involved in learning it is possible that the achievement of learning (learning outcomes) will be more optimal to give a produce young entrepreneurs who are competitive in their expertise.

Related to that matter, the leaders of a business rely on the convergence of experience and social capital to learn different skills and knowledge that is relevant to social entrepreneurship. Direct experience can be gained through a volunteer work, experience with religious institutions, social activism, formal education, professional experience, reading and interaction between cultures. It proved to be an important experience in the trajectory of learning from the leaders [9].

To facilitate the learning experience of students, the designers and developers of software need to create a tool or technology that affect teachers, school leaders, students, and their families. In order to create something new, it needs to conduct an analysis of needs in the education system by highlighting the critical needs and opportunities to develop digital tools and applications to learn. In that respect, [3] try to find a guidebook for students, teachers and families in the development of entrepreneurial skills. The researchers change the teaching by facilitating the student through: (1) Improving the mastery of academic skills; (2) Developing the ability to promote lifelong learning; (3) Increasing the family involvement; (4) Planning for future educational opportunities; (5) Designing effective assessment; (6) Increase the development of professional educators; (7) Increase the productivity of educators; (8) Make learning accessible to all students; (9) Closing the opportunity of any gap; and (10) Closing the achievement gap.

Other experiences that can be adopted in the development of entrepreneurial skills is in a social enterprise experience that offers the promise of financially sustainable organization that can respond to the pressing problems in the world. The leaders must be effectively committed to improve the social welfare and achieve the economic viability of the community. Then, prospective employers or entrepreneurs are given the same experience to make successful entrepreneurs as role models. [14] in a study conducted an experiment using two arrangements to educate employers. The experiment was conducted in a class and in a field, to describe a pedagogical tool in teaching entrepreneurial skills. The implementation of the program was by integrating the challenges, skills and pedagogical tool. The result is that effective to develop entrepreneurial skills. 
A question in entrepreneurship education is "Can entrepreneurship be taught?". To answer this question, a study found that being an entrepreneur requires direct experience, and explores how to learn through actionbased approach. The challenge of assessing entrepreneurship education has also contributed to the dominance of the cognitive approach in entrepreneurship education, although they are not able yet to develop entrepreneurial competence. According to [14] an entrepreneurship education program for two years in Sweden held a "paradigmatic case" of action-based entrepreneurship education, defines "business creation approach" and justify a single case study approach. Thirteen students of the program learned to use the framework for the interpretation of entrepreneurial competence. In this context, the development of entrepreneurship was based on "mobile application".

Furthermore, research [8] revealed 17 types of events that can be associated with the development of entrepreneurial competencies. According to preliminary findings, the samples are such as the interaction with the outside world that leads to entrepreneurship, marketing skills and tolerance. Four classes in the study could help practitioners based on action-entrepreneurship education to compare the different pedagogical approaches and then decided which activities to choose in certain teaching situations. They helped the researchers to focus on relevant aspects of the action-based entrepreneurial education, removing irrelevant differentiation for the purpose. If such a causal relationship was exists, it will open a new approach for an assessment in entrepreneurship education where the focus is on the frequency, strength and a certain kind of emotional events.

The implications of this study are all components of education and learning must be involved to give the students opportunity to have a direct experience. Further impacts to society is that a paradigm of being a job seeker to job creator.

\section{Support and challenge in Product Based Learning}

Applying the product based learning is not an easy matter, which is solely charged to students to remain active and give the independent tasks to students to support their learning experience. However, teachers or lecturers demanded to be competent in drafting and developing entrepreneurship learning plan so that students are able to explore their creativity, their abilities, independent, and be able to gain direct experience in the learning process. Not only that, the learning outcomes of entrepreneurship learning is not solely the result of learning or experience gained by the student in the process of learning, the students are required to be brave and go jump into the world of entrepreneurship in accordance with their areas of expertise, as well as their knowledge. According to that matter, all teachers or lecturers of entrepreneurship courses are the key to realize an optimal entrepreneurial learning process.

The model of product based learning in the course of entrepreneurship is in contrast with the developments that have been made previously, as has been stated above that this model is a combination of the three characteristics of constructive learning model, which are Project based learning, active learning, and Experiential Learning. After making the comparison, then syntax-syntax that are considered can realize the quality of teaching entrepreneurship in line with expectations both in terms of educators' aspects (Pedagogy Capability) and students (learning outcomes) are formulated. Here are the steps (syntax) that is developed in the model of product based learning. 


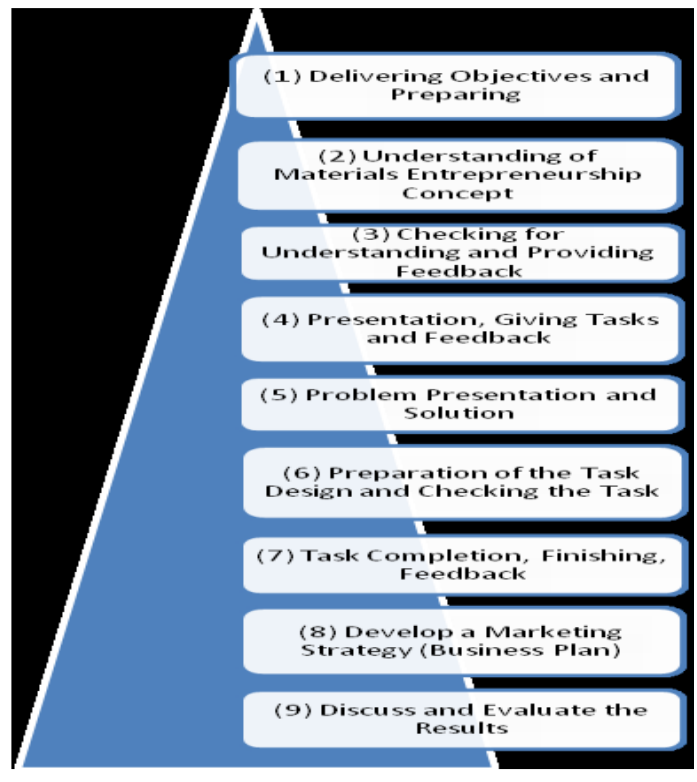

\section{CONCLUSION}

Enactment of AEC (ASEAN Economic Community) in 2016, is a challenge that must be answered by Indonesian nation with various readiness and policy reforms that must be carried out in various sectors. One of them is in the vocational education sector, where higher and vocational education is an important factor in producing qualified graduates that highly qualified so that they are ready and be able to compete in liberal market. Thus, improving in the learning needs to be done in curriculum, models, strategies, and methods used, especially in entrepreneurship education. By direct experience obtained by the students in the application of product based learning, it is expected that they can handle the existing problems and achievement of entrepreneurship education in order to increase the number both of college graduates and young entrepreneurs in accordance with their field and knowledge.

In order to realize all of goals, it is necessary to enhance the competence of lecturers to develop and arrange the lesson plans to facilitate the students in developing their ability, courage, and autonomy in entrepreneurship and become sensitive to the needs and developments in the industrial world. Therefore, based on the challenges in regional, national, and global that we will encounter, it needs a learning model that is capable to explore the student's ability to develop their potential so that they have creativity in entrepreneurship in accordance with their knowledge.

\section{REFERENCES}

[1] Agung W, "Entrepreneurship Education in Vocational Schools: Characteristics of Teachers, Schools and Risk Implementation of the Curriculum 2013 in Indonesia", Journal of Education and Practice ISSN 2222-1735 (Paper) ISSN 2222-288X (Online) Vol.7, No.9, 2016), pp. 122-127.

[2] Amir, Muhammad Taufik. Entrepreneurial Behavior and Innovative Behavior: A Conceptual Clarification. The Asian Journal of Technology Management (AJTM) Vol 8, No 2 (2015).

http://dx.doi.org/10.12695/ajtm.2015.8.2.7

[3] Bienkowski, Marie; Gerard, Sarah Nixon; Rubin, Shawn; Sanford, Cathy; Borrelli-Murray, Dana; Driscoll, Tom; Arora, Jessie; Hruska, Mike; Beck, Katie; Murray, Thomas; Hoekstra, Jason; Gannes, Stuart; Metz, Edward; Midgley, Steve; Castilla, Stephanie; Tomassini, Jason; Madda, Mary Jo; Chase, Zac; 
Martin, Erik; Noel, Marcus; Styles, Kathleen. 2015. Ed Tech Developer's Guide: A Primer for Software Developers, Startups, and Entrepreneurs. Office of Educational Technology; 68

[4] Brady, L \& Kennedy. Curriculum Constructions. Frenchs Forest,. NSW: Pearson, Prentice Hall. 2007

5] Edwards, Louise-Jayne; Muir, Elizabeth J. 2012. Evaluating Enterprise Education: Why Do It?. Education \& Training, v54 n4 p278-290 2012: 13

[6] Ganefri. 2013. The Development of Production-Based Learning Approach to Entrepreneurial Spirit for Engineering Students. Journal Asian Social. Science; Vol. 9, No. 12; 2013. ISSN 1911-2017 E-ISSN 19112025

[7] Kemenristekdikti. Dokumen 001, Kerangka Kualifikasi Nasional Indonesia. Jakarta : Kementrian Riset Teknologi dan Pendidikan Tinggi. 2015

[8] Lackéus, Martin. 2013. Developing Entrepreneurial Competencies: An Action-Based Approach and Classification in Education. Division of Management of Organizational Renewal and Entrepreneurship Department of Technology Management and Economics Chalmers University Of Technology

[9] Laura, Scheiber. Social Entrepreneurs in Rio De Janeiro: Learning Experiences and Social Capital.2012.

http://academiccommons.columbia.edu/catalog/ac:146422

[10] Markus Th. Eickhoff "Entrepreneurial thinking and actionan educational responsibility for Europe". European journal of vocational training, No 45, 2008/3 - ISSN 1977-0219)

[11] Nitin, Bajaj. Examining Entrepreneurial Motivations of Indian Immigrants. Pro Quest LLC. ISBN:978-1-3037-9127-7, 122. 2014

[12] Onstein, A.C. \&Hunkins, F.P. Curriculum: Principles, Foundation sand Issues. Englewood Cliffs, N.J.: Prentice Hall. 2013

[13] Permendikbud No. 73 Tentang Penerapan Kerangka Kualifikasi Nasional Indonesia Bidang Pendidikan Tinggi. Jakarta: Kementrian Pendidikan dan Kebudayaan. 2013

[14] Smith, Wendy k; Besharov, Marya 1.; Wessels, Anke k; Chertok, Michael. 2011. A Paradoxical Leadership Model for Social Entrepreneurs: Challenges, Leadership Skills, and Pedagogical Tools for Managing Social andCommercial Demands Academy of Managemen Learning \& Educafion, 2012, Vol. II, No. 3, 463-478. http://dx.doi.org/10.5465/amle.2011.002 463-479

[15] Sullivan, Robert. "Entrepreneurial learning and mentoring", Internasional Journal of Entrepreneurial Behavior \& Research, Vol. 6Iss: 3, 2000. pp.160 - 175

[16] Suryana, "Kewirausahaan Pedomal Praktis: Kiat dan Proses Menuju Sukses", Vol. 3, Publisher Salemba, Jakarta. 2006.

[17] Zais, Robert S. Curriculum: Principles and Foundations. New York: Crowell Company, Inc.1976 